Chapter 1

\title{
An Overview of The Public Health Global Perspective on the Grand Challenges of Non-Communicable and Chronic Diseases Within the Framework for Developing new Drugs
}

\author{
Estella Tembe-Fokunang, Charles Fokunang, \\ Zacharia Sando, Barbara Atogho Tiedeu, \\ Frederick Kechia, Valentine Ndikum, \\ Marceline Ngounoue Djuidje, Jerome Ateudjieu, \\ Raymond Langsi, John Fomnboh Dobgima, \\ Joseph Fokam, Luc Gwum, Obama Abena, \\ Tazoacha Asonganyii, Jeanne Ngongang, \\ Vincent K. Titanji and Lazare Kaptue
}

Additional information is available at the end of the chapter

http://dx.doi.org/10.5772/59070

\section{Introduction}

Non-communicable diseases (NCDs) known to cause more than half of all deaths in sub Saharan Africa over the past two decades has shown a steady increase to become a public health concern,. [1-4]. More than 30\% of these deaths are recorded before the age of 60 in the resource poor countries. The mortality and morbidity caused by the NCDs is globally on the increase. However, the greatest impact has been recorded in sub Saharan Africa where healthcare facilities and medical awareness is low. In the developing countries NCDs is on the rise at the same proportion with infectious diseases that has led to an increasing disease burden, [2].

Other studies in sub-Saharan Africa has indicated that women within the ages of 15-49 are dying from NCDs faster than the women living in high-income countries [3-4]. The burden of 
early mortality and disability poses a serious problem to socio economic and human development [3]. In countries where the public health systems are not well developed, payment for health care service for the poor is difficult and creates more financial burden to the poor subsistent population. The assess to treatment for metabolic disease such as diabetes has been shown to cost a patient in some developing economies like India about $15-25 \%$ of their household earnings [5-6]. Studies conducted by the World Bank showed that cardiovascular disease can lead to high expenditure for about $25 \%$ of India families and also creates poverty to about $10 \%$ of low income families [5-7]. The socio economic implication of population living with NCDs ranges from time off work usually unpaid, high unemployment rate and also early retirement from work. [6-8]. the world economic forum (WEF) based on socio economic situation in developing economies attempts to place the NCDs among the top global concern to economic empowerment [6-8].

Well-structured and coordinated primary prevention with elaborate health care disease surveillance can potentially help reduce in developing countries like Africa [8].Base on the good health care policy implementation strategies there has been a concerted effort by health actors to develop and formulation of effective health programmes for the prevention and potential control strategies for NCDs that was initiated during the World Health Assembly that took place 2000. Some great initiatives has been implemented by WHO member countries towards the control of tobacco consumption, an unregulated excessive alcohol intake, and the global control of diet and nutrition, physical activity and health. A lot of effort has been taken to reduce potential NCDs as indicated report in the action plan of WHO of 2008-2013 [8-10]. In the sub Saharan Africa regions the reduction of NCDs is not view as a technical resource issue, but it is a highly political problem which in most cases does not create an enabling health working environment. The health sectors and the policy-makers in most sub Saharan African countries are aware of the burden of NCDs, and also the existence of cost-effective interventions for implementation, unfortunately health intervention policy is not priority [10-12]. So far, some donors and the international development community have been slow to respond, in part because NCDs are not among the Millennium Development Goals [11]. So far with all the repeated donor mobilization and commitments as demonstrated by the Paris Declaration on Aid Effectiveness and the Accra Agenda for Action, NCDs still receive below $3 \%$ of the development assistance for health across most countries in sub-Saharan Africa despite the fact that NCDs are known to cause more than of all premature deaths in these regions [11-14].

The WHO's Action Plan for the Global Strategy for the Prevention and Control of NCDs has put in place a strategic health development platform for change and since its adoption in 2008, a global movement promoted by leaders from developing countries to develop a common partnership operational platform is effective to some extend [14-16[.The Some partnership global initiative has led to important decisions like that taken at Doha which led to some resolution and declarations made on NCDs and different injuries advocating consideration for integrating the NCD prevention and control into the health management framework [16]. Deliberations at the United Nations Economic and Social Council meeting in July 2009 led to a United Nations General Assembly Resolution in May 2010, requesting the United Nations to convene an important meeting in September 2011 inviting the participation of heads of state 
and government [17-18]. Drawing inspiration from the HIV/AIDS crucial meeting in 2001 that was the turning point in unlocking the HIV epidemic, this meeting also provided an opportunity to raise awareness and shift in paradigm in research towards the NCDs within the framework of the global health development agenda [19-21].

The distribution of the burden $\mathrm{f}$ NCDs has shown a big disease gap between the high income earning countries where the health service is very developed and organized and the low income countries where the health system is not well organized and less accessible to the poor subsistence population as shown in Figure 1. There disease burden is more severe with the highly active population within the age range of $15-59$ years recording between $48 \%-56 \%$.
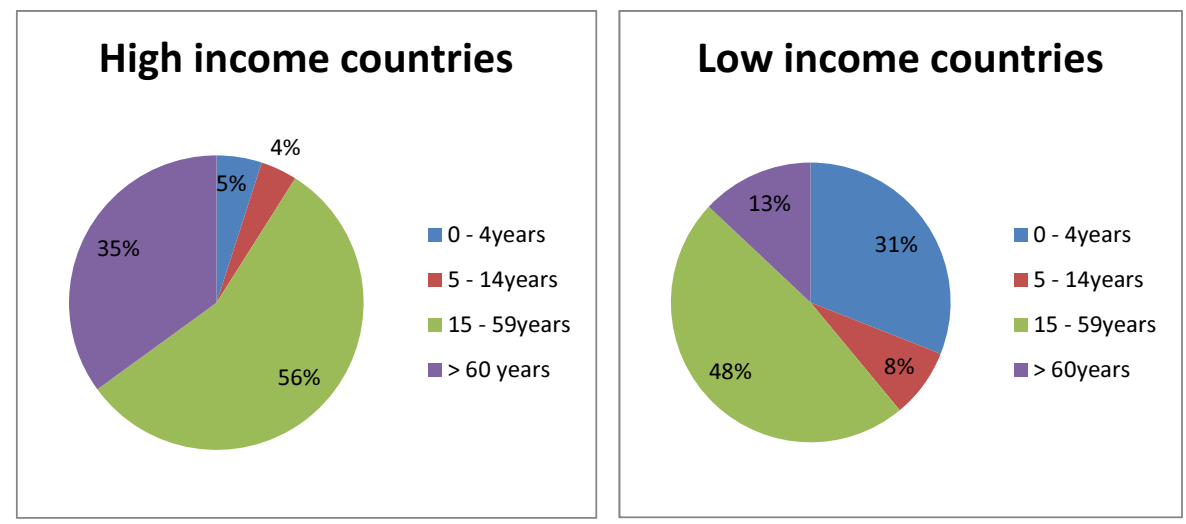

Figure 1. Disease burden distribution in high income and low income countries (Data source-WHO 2013) [26]

Many efforts have been made to organize important workshops, conferences on NCBs through the support of Global Health, and stakeholders in health within the WHO mapped sectors, and in Africa coordinated by the new partnership for Africa (NEPAD), Africa Union support programmes.

Workshops and consultation forums have contributed towards the production of vital support documents that serve in the promotion of awareness on NCDs and also important end of meeting resolution are made through national declaration by the health sector stakeholders that helps in identifying and targeting strategic areas for possible control intervention. In some developing countries efforts have been made towards the creation the health actors' national programmes to deal with NCDs through national consultations and coordination that requires a high level of commitments from the health stakeholders. There is effort made toward putting in place a well-developed health monitoring system for sector action evaluation, accountability and participation potential of the NGOs and other affiliated nonpublic health actors, the public health partnership sectors and to a greater extend efforts made to enhance the strategies promoting the action plan of established by WHO [22-24]. Resolutions and declarations form organized symposiums and many organized conferences helps in setting priorities by policy makers within the WHO member states and a roadmap to put in place sustainable 
implementation strategies. There is the need for the promotion of the awareness and sensitization of NCDs through the outcome of a consultation frame work organized by the health sectors in the WHO members states, at the level of research institutions, research groups focused on developing and establishing effective policy and legislation that supports NCDs portfolios [25].

To develop good control strategies for NCDs there is the need for total participation of the entire public health sectors, actors in health research institutions. The holistic approach involving the total participation of all stakeholders has shown to be more effective for a sustainable NCDs in Africa and also support resource poor countries to implement good control programmes, and channel public health policies towards the intensification of the prevention action and capacity strengthening for NCDs control and management systems [24-26]. In the WHO member states where there is well organized structures to support and promote health professionals leadership and the efforts to promote NCDs management initiatives, are known to play a significant role in shaping study of the epidemics and managing the cases of premature deaths in Africa [4, 7, 27]..Some of the main indicators of diseases that are used such as disease incidence and prevalence, do not give a clear indication when considering the disease burden involving an individual in a community in poor resource economy

The unit measure for that is applied to express an indication of the disease burden is known as the DALY and one DALY which represents the loss of the equivalent of one year of full health [27]. By using the DALYs, measurement the disease burden involve in early deaths and little disability such as measles or drowning, could be compared to other diseases that cannot cause death but has potential to cause disability as the case of cataract that causes blindness [1, 2, 28-29] NCDs is known to cause about half of the disease burden in the low-and middleincome countries [22-24], and about one half of the disease burden involves non-communicable diseases. Among the NCDs Ischaemic heart disease and stroke constitutes the biggest sources of this disease burden and the cardiovascular diseases account for more than one quarter of the total disease burden. Currently, injuries have been shown to account for about $17 \%$ of the disease burden in adults aged $15-59$ years, within the low- and middle income economies in Europe, USA and the Eastern Mediterranean Regions, where more than 30\% of the entire disease and injury burden are recorded among men aged between 15-44 years. [29-30].

\subsection{Leading causes of burden of disease}

Recent studies have shown that the four non-fatal conditions are found in the 20 leading causes of burden of disease, while the two leading causes of death such as ischaemic heart disease and cerebrovascular disease, and are among the top six causes of burden of disease as indicated in table 1 . The four primarily non-fatal conditions are also shown to be among the 20 leading causes of burden of disease; such as hearing loss, alcohol use disorders, and unipolar depressive disorders to name but a few.. To assess the main causes of loss of health in any populations it is very relevant to take into consideration the non-fatal conditions as well as deaths. The income levels are also known to be linked with major differences in burden of disease [3-5]. The two leading causes of burden of disease in the world are infectious diseases such as lower respiratory infections and diarrheal diseases. HIV/AIDS is known to be the fifth cause of 
burden of disease globally, and three other infectious diseases follows on the top 15 causes as shown in Table 1.The leading causes of burden of disease in developing nations are very similar to those recorded globally, with the exception of the statistics for malaria and tuberculosis (TB). As indicated in Table 1, out of the top ten causes of death, eight belongs to the Group I, however the leading causes in developed nations are all NCDs, with the exception of road traffic accidents which is the tenth leading cause of death [29-30].

\subsection{The disease and injury burden for women}

In a broader perspective depression is now known to be among the leading cause of disease burden among young adult women with mental disorders that are known as the main source of lost years of healthy life for women of aged 15-44 years [23].Mental disorders make up three of the ten leading causes of disease burden in developing countries, and four of the leading ten in developed countries. Case of self-inflicted injuries have been reported to be among the leading ten causes for the developing economies [3, 11, and 30]. Injuries have also been shown to be important for boys beyond infancy, however, the causes of burden of disease are broadly similar for boys and girls but with, a marked sex differences that is seen between the age range of 15-59 years. The burden of reproductive problems is generally restricted to developing nations, and this is vital such that the maternal conditions make up two out of the ten leading causes of disease burden in women of age groups 15-44 years [29-30]. The HIV/AIDS, and other maternal conditions are among the main factors contributing to the high disease burden for women in developing countries with respect to developed countries. In sub Saharan African and in the South-East Asia regions, the disease burden from maternal conditions is responsible for about eight percent of the total global disease burden shown in women between the aged groups of 15-59 year [32-34]. In developing countries great contribution can be made towards reducing the burden of disease by developing strategies aim at reducing loss of healthy years that can be enhanced by putting in place better facilities to implement proper care for pregnant women, promote antenatal and neonatal care, years loss Almost all of this loss of healthy years of life is avoidable.in low-income countries, better care for women in pregnancy and childbirth could make a great. The Millennium Development Goal provides an opportunity for women to have access to a skilled birth attendant during childbirth. This opportunity where available has reduced to a greater extent the disease burden through the prevention maternal and neonatal deaths. $[9,35]$.

\subsection{Causes of non-communicable disease}

The burden of NCDs are derived from various past and cumulative risks; and the future burden are now determined by current population exposures to risk factors. Studies have shown that the major risk factors for NCDs epidemics are more complex than those for infectious disease and are well known to be responsible for most of such risk factors. [2-6]. Many populations are exposed to the most common groups of NCDs. There are some modification of these NCDs within individuals and location but generally the mode of action is the same worldwide [9-12]. Some determinants on NCD epidemics involves the increase in aging population, low fertility and the decreasing child survival potential 
The increase in NCDs globally has been caused by a significant change in lifestyle of the population especially in developing economies. Current trends indicates that more people spend longer period out of their homes working and eating fast food containing high cholesterol level which is a predisposing factor to metabolic diseases, with obvious implication linked to problems such as low fertility and sexual dysfunction [32-34].

World trade and marketing developments concepts is to orientate the nutrition and food strategies transition towards diets formulation with a high proportion of saturated fat and sugars with high cholesterol. The consumption of high cholesterol diet, drug abuse, and common tobacco use with little or no physical activity can lead to worldwide predisposition of NCDs [15-17]. In developed countries, seven of the ten leading risk factors contributing to the burden of disease are for non-communicable disease, compared with six and three of ten in developing countries with low and high rates of mortality, respectively

\subsubsection{Non-communicable disease risk}

The NCD risks are higher in developing countries and dominate the disease burden of most developed countries, to the extent that they are considered as a health priority in the developed countries [11, 35].The developed countries have well-structured health programmes to manage the NCD risks which generally increase with age. It is therefore important to develop control measures of the different age distributions of populations through age-standardization of DALY rates, to reduce the apparent NCDs risks. Report on the age-standardized DALY rates, are higher in developing countries than in developed nations [35-37]. This disparity is due mostly to cardiovascular diseases, such as the heart disease and stroke, with age standardized burden are significantly higher in developing nations than in developed countries. Other disease burden under the group of sense disorders, vision impairment and ocular anomaly like hearing loss, is more common in developing economies than in the developed countries [35-37].

\subsubsection{The Global unequal burden of disease injury}

Other reports show that one sixth of the disease burden in adults caused by injuries accounts for $17 \%$ of the disease burden in adults aged between 15-59 years [35-37]. In developing countries about $30 \%$ of the main disease and injury burden recorded in men between the ages of 15-44 years are known to result from injuries. In general considering both sexes, road traffic accidents are the third leading cause of burden in the 15-44 age group that is followed by HIV/ AIDS and unipolar depression. Due to economic decline and poor road infrastructural development there is a rapid increase in road traffic accidents most especially in the developing countries [12, 38].The relative importance of intentional injuries varies from regions to regions and these category of injuries includes aspects like self-inflicted injuries, suicide, violence and war [37-39]. This type of injury contributes to the increasing rate of the burden, mainly in economically oriented young adults. In most developed nations, suicides top the cause of intentional injury burden, while low income economies aspects of violence and war leading the massive displaced and migratory population are the main cause. Highly politically unstable regions involve in unrest, civil wars like in the Central Africa sub regions, have rates 
of injury, death and disability among males that are similar to other developing countries [5, 30, and 39]. The death rate resulting from the effect of poisoning is significantly high developing countries than in any other region of the world. Consumption of excess and deaths is also a main cause in developing countries where the unemployment rate is very high and provokes frustration among the youth. Record of the potential death rate resulting from injuries cause by fire is significantly higher for women population in the South-East Asia regions than for the women or men population globally [40].

\subsubsection{Global Projection of the burden of disease in 2035}

The global forecast for the disease burden per capita is projected to potentially show a decrease in the global DALYs from 1.53 billion in 2014 to about 1.36 billion in the year 2035, given a general decrease of approximately $10 \%$ [40-42]. There is also a projection of increase in population of over $25 \%$ during the same time span, which represents a big decrease in the general per capita disease burden worldwide. The DALY rate general have been shown to decrease faster than the global death rate due to a potential shift in the chronic NCDs that has not only occurred in the last decade but has become an economic health issue, that has attained an epidemic magnitude globally [11, 43-45].

Within the coming years the burden of chronic NCDs is anticipated to be on the increase particularly in sub Saharan Africa. This projection raises a concern of the potential death of about 388 million people in the population in the next decade from one or more forms of CNCDs. This health concern has provoked many states to put in place some action plans towards reducing a significant number of premature deaths. [21, 46]. There is the possibility that poor feeding and excessive smoking are two important factors that contribute to the millions of preventable deaths that occur each year.The CNCDs have a significant negative economic impact such that looking at the next 1o years, south east Asia, the UK and India are listed to lose billions in combating the CNCDs.[47-49], Within the framework of globalization, the increasing interconnection of countries and the openness of borders to ideas, people, commerce, and financial capital, has beneficial and harmful effects on the health of populations $[2,14,50]$. The effect of the present current era of globalization on health has to be debated and reconsidered in a wider perspective $[5,52]$. Greater emphasis and interest is now focused on the control strategies on the infectious diseases and the threats to world security, the supply of generic drugs and international trade partnership [41, 52].

\subsection{The global burden of non-communicable disease and disease injury distribution}

Health forecasts projection shows that there are about 56 million deaths globally, of which about $60 \%$ die as a result of NCDs [53]. 16 million deaths are recorded from cardiovascular disease (CVD), especially the coronary heart disease (CHD) and stroke; 7 million from cancer; 35 million from chronic respiratory disease; and almost 1 million from diabetes [41,52]. Mental health problems are known to be the leading cause of disease burden in most countries irrespective of its state of development and this contribute in many ways to the incidence and severity of many NCDs such as the cardiovascular disease and cancer [1,53]. The disease injury distribution has been grouped into world disease regions of Africa, the Americas, and the 
Eastern Mediterranean and European regions. This distribution are well illustrated in Table 1 , showing the disease injury categories and the DALY. It is observed that there is major variation between these world disease regions.

\begin{tabular}{|c|c|c|c|c|c|c|c|}
\hline \multicolumn{2}{|c|}{ Disease incidence or injury } & \multirow[t]{2}{*}{$\begin{array}{l}\text { DALYs } \\
\text { (millions) }\end{array}$} & \multicolumn{2}{|l|}{$\begin{array}{l}\text { Percent } \\
\text { of total } \\
\text { DALYs }\end{array}$} & Disease or injury & $\begin{array}{l}\text { DALYs } \\
\text { (millions) }\end{array}$ & \multirow[t]{2}{*}{$\begin{array}{l}\text { Percent of } \\
\text { total } \\
\text { DALYs }\end{array}$} \\
\hline & The African sub Regions & & & & The Region of the Ameri & & \\
\hline 1 & HIV/AIDS diseases & 46.7 & 12.4 & 1 & $\begin{array}{l}\text { Unipolar depressive } \\
\text { disorders }\end{array}$ & 10.8 & 7.5 \\
\hline 2 & $\begin{array}{l}\text { Lower respiratory tract } \\
\text { infections }\end{array}$ & 42.2 & 11.2 & 2 & Violence abuse & 6.6 & 4.6 \\
\hline 3 & $\begin{array}{l}\text { Diarrheal (gastroenterological } \\
\text { issues }\end{array}$ & 32.2 & 8.6 & 3 & $\begin{array}{l}\text { cardiovascular disease } \\
\text { problems }\end{array}$ & 6.5 & 4.6 \\
\hline 4 & Malaria infections-PRD. & 30.9 & 8.2 & 4 & Alcohol abuse disorders & 4.8 & 3.4 \\
\hline 5 & $\begin{array}{l}\text { Neonatal and antenatal } \\
\text { infections and other }\end{array}$ & 13.4 & 3.6 & 5 & $\begin{array}{l}\text { Unstained Road traffic } \\
\text { accidents }\end{array}$ & 4.6 & 3.2 \\
\hline 6 & $\begin{array}{l}\text { Birth asphyxia and birth } \\
\text { trauma }\end{array}$ & 13.4 & 3.6 & 6 & Diabetes mellitus & 4.1 & 2.9 \\
\hline 7 & $\begin{array}{l}\text { Premature and low birth } \\
\text { weight }\end{array}$ & 11.3 & 3.0 & 7 & Cerebrovascular disease & 4.0 & 2.8 \\
\hline 8 & Tuberculosis problems-PRD & 10.8 & 2.9 & 8 & $\begin{array}{l}\text { Lower respiratory } \\
\text { infections }\end{array}$ & 3.6 & 2.5 \\
\hline 9 & Road traffic accidents & 7.2 & 1.9 & 9 & $\begin{array}{l}\text { Chronic obstructive } \\
\text { pulmonary disorder } \\
\text { COPD }\end{array}$ & 3.1 & 2.2 \\
\hline 10 & Protein-energy malnutrition & 7.1 & 1.9 & 10 & $\begin{array}{l}\text { Congenital malformation } \\
\text { anomalies }\end{array}$ & 2.9 & 2.1 \\
\hline
\end{tabular}

The Eastern Mediterranean sub

The European sub Regions

\section{Regions}

\begin{tabular}{|c|c|c|c|c|c|c|c|}
\hline 1 & Lower respiratory infection & 12.1 & 8.5 & 1 & $\begin{array}{l}\text { Cardiovacular heart } \\
\text { disease }\end{array}$ & 16.8 & 11.1 \\
\hline 2 & Diarrheal diseases & 8.3 & 5.9 & 2 & Cerebrovascular disease & 9.5 & 6.3 \\
\hline 3 & Ischaemic heart disease & 6.2 & 4.3 & 3 & $\begin{array}{l}\text { Unipolar depressive } \\
\text { disorders }\end{array}$ & 8.4 & 5.6 \\
\hline 4 & Neonatal infections and other & 6.1 & 4.3 & 4 & Alcohol use disorders & 5.0 & 3.3 \\
\hline 5 & Cot death and birth trauma & 5.5 & 3.9 & 5 & Hearing loss, adult onset & 3.9 & 2.6 \\
\hline 6 & $\begin{array}{l}\text { Premature death and low birth } \\
\text { weight }\end{array}$ & 5.3 & 3.8 & 6 & Road traffic accidents & 3.7 & 2.4 \\
\hline
\end{tabular}




\begin{tabular}{|c|c|c|c|c|c|c|c|}
\hline & ase incidence or injury & & & & Disease or injury & DALYs & \\
\hline 7 & Unipolar depressive disorders & 5.2 & 3.7 & 7 & $\begin{array}{l}\text { Trachea, bronchus, lung } \\
\text { cancer }\end{array}$ & 3.3 & 2.2 \\
\hline 8 & Road traffic accidents & 5.1 & 3.6 & 8 & Osteoarthritis & 3.1 & 2.1 \\
\hline 9 & War and conflict problems & 3.8 & 2.7 & 9 & Cirrhosis of the liver & 3.1 & 2.0 \\
\hline 10 & Congenital malformations & 3.7 & 2.6 & 10 & Self-inflicted injuries & 3.1 & 2.0 \\
\hline & South-East Asia sub Regions & & & The & Western Pacific sub Region & & \\
\hline 1 & Lower respiratory infection & 28.3 & 6.4 & 1 & Cerebrovascular disease & 15.8 & 6.0 \\
\hline 2 & Diarrheal diseases & 23.0 & 5.2 & 2 & $\begin{array}{l}\text { Unipolar depressive } \\
\text { disorders }\end{array}$ & 15.2 & 5.7 \\
\hline 3 & Ischaemic heart disease & $21 . .6$ & 4.9 & 3 & COPD & 11.9 & 4.5 \\
\hline 4 & Unipolar depressive disorders & 21.1 & 4.8 & 4 & Refractive errors & 10.6 & 4.0 \\
\hline 5 & $\begin{array}{l}\text { Prematurity and low birth } \\
\text { weight }\end{array}$ & 18.3 & 4.1 & 5 & Road traffic accidents & 9.6 & 3.6 \\
\hline 6 & Neonatal infections and other & 14.3 & 3.2 & 6 & Alcohol use disorders & 8.6 & 3.2 \\
\hline 7 & $\begin{array}{l}\text { Birth asphyxia and birth } \\
\text { trauma }\end{array}$ & 13.9 & 3.1 & 7 & Ischemic heart disease & 7.9 & 3.0 \\
\hline 8 & Tuberculosis & 12.4 & 2.8 & 8 & Hearing loss, adult onset & 7.0 & 2.6 \\
\hline 9 & Road traffic accidents & 11.0 & 2.5 & 9 & Birth asphyxia and trauma & 5.7 & 2.1 \\
\hline 10 & Cerebrovascular disease & 9.6 & 2.2 & 10 & Tuberculosis & 5.6 & 2.1 \\
\hline
\end{tabular}

COPD, chronic obstructive pulmonary disease PRD-poverty related diseases

Table 1. Global disease injury distribution in the world disease regions of Africa, the Americas, Eastern Mediterranean region and European Region [13, 29].

There are all indications that communicable diseases in Africa cause more deaths than noncommunicable diseases. NCDs contribute significantly to adult mortality with the highest rates recorded in central and eastern European sub regions [54]. They increase the problem of health inequalities within and between affected countries, mainly concerning poor populations due largely to the inequalities in the distribution of major risk factors [3, 55-56].

\section{The effects of globalization on disease burden}

The study on economic and financial globalization and the World Trade Organization (WTO) show that when the national and the international trade is regulated this can lead to improvement of the health status of the population, although this benefit has little impact in developing countries [7]. Many countries have put in a lot of efforts towards the regulation of national and 
international trade unfortunately, the limited resources and technical knowhow has not helped to promote the programme. WTO promotion of drug development and new chemical entities has enhance the access to many developed pharmaceuticals, but not all countries have same accessibility due to lack of limited resources. [5,9]. The development of NCD epidemics where there are limited access to medical care has been influence to some extend by globalization [1-3]. The effect of indirect effects of globalization are linked to national economic performance which act through changes in household income, government spending, and the foreign exchange, and prices regulation within the different countries [50]. National income play an important role in health development however in developing countries the resources for health promotion [51-43]. Some of the drawbacks of globalization on health can be exemplified by increase in production and commercialization of unfriendly health products such as alcohol, tobacco and other substances of health abuses readily available to the population. These commodities unfortunately are very accessible to the population especially in the developing countries where trade regulation of these products where there exist are difficult to enforce. $[36,54]$.

Significant efforts have been made towards the protection of essential local producers in high income economies and this has had an effect on the management of NCD epidemics. For instance the move by the European Union (EU) to subsidize agricultural products is aimed at regulating the competition that may arise from the primary producers. There is little subsidize unfortunately for fresh produce in low income economies and therefore could reduce the national income [55]. The EU also subsidize the production of tobacco which has been generally considered as a policy anomaly because of the negative health effect tobacco has on the population of consumers. [31, 45,56]. Some attempts have been made through advocacy for the removal of the agricultural subsidies and this was endorsed in Doha and then in Johannesburg during the World Summit on Sustainable Development and most recently the declaration by the EU gave an indication that the process for lifting subsidies linked to production is in progress.

Modern information and communication technologies (ICT) have been shown to have some positive and negative effects on health. It is evident that global commercialization of products like tobacco, alcohol, and other essential household products could be made available to all parts of the country ICT has made it possible for global commercialization shifting market target to the younger population $[3,11]$. In the USA for example millions of dollars are put into persuasive marketing that has encourage young people to develop interest in fast food with high cholesterol content, fizzy drinks, alcohol and tobacco. The power of media publicity and advertisements through the use of more sophisticated technology has promoted the persuasive marketing and also exploiting the poor regulatory environment to capture and penetrate the consumer market [21-26].

\subsection{Globalization, nutrition and alcohol on disease burden}

Nowadays there has been a great substitution of our natural organic traditional food rich in fruit, vegetables and fibers by diets rich in calories from animal fats and low in complex carbohydrates. The impact of this food substitution syndrome has had more impact in 
developing countries [3. 11, 17]. Such changes has led to an increased rates of many NCDs in countries previously protected by balanced and healthy diets. Sub-Saharan Africa, Asia and some South American countries are undergoing a big shift in consumption patterns, and consumer life style transformation although rates of heart disease are still low compared to developed countries, and stroke rates have also reduced significantly in countries like Singapore and Japan [46]..

Globally there has been a steady increase transformation in farming [45] food processing, distribution [23] transportation [19] shopping practices [3, 55] and the consumption of food outside of the home (fast food, take away) [27]. Cooking has changed with the development of microwave, ovens and other techniques and changing lifestyles, especially in the urban cities where people work long hours out of home [14]. Changing patterns of production and consumption underlie the emergence of NCD epidemics and poses a problem to achieving a sustainable development goals [56]. The impact of alcohol consumption in promoting noncommunicable disease epidemics has become very complex and a significant correlation has been shown between alcohol consumption and liver cirrhosis, some cancers, and most causes of injuries and violence. Alcohol also enhances and predispose the population to the risk of cardiovascular disease [22, 36].

\subsection{Global policies towards non-communicable disease control strategy}

\subsubsection{Prevention strategy}

The progression of non-communicable disease, especially lung cancer in men and CVD, have reduced significantly in many developed countries than in low income economies. For example in lung cancer, the reduction in mortality is linked to the concerted prgramme developed to reduce tobacco consumption by the population [50-52]. There are indications that, in many European countries, and south East Asia lung cancer epidemics is on the increase especially in women. This increase is linked to the rise in smoking habit developed in women and the lack of traditional health promotion programmes to enhance regulation of tobacco marketing strategies oriented towards young women [9]. The cause of reduction in CVD mortality are complex but are linked to improved management in high risk people, in particular in the USA, and in some countries, such as Finland and Sweden, where there are prevention programmes aimed at reducing the risk levels in combination with other environmental changes within the population [46].

The application of existing knowledge could play a major, rapid, and cost-effective contribution to the prevention and control of NCD epidemics [18]. The agenda of most international donors is focused on belief that communicable diseases can be prevented or treated before addressing the problems of NCDs [45]. The report made by the Commission on Macroeconomics and Health did not consider as a priority to make any emphasis or awareness on the importance of the growing burden of NCDs [7], this is probably because of the misconception that NCDs are still the preserve of wealthy countries and populations. Generally in developing countries the institutional response to disease prevention and control is still based on the infectious disease paradigm [15,34].and therefore the global and national ability in managing 
non-communicable disease epidemics is very inadequate and few countries have successfully put in place a workable prevention and control programmes [1, 16].

\subsubsection{Global advocacy for non-communicable disease}

The sensitization and active advocacy is still at its infancy at the global level for NCD prevention and control [8], and even the control platforms developed in advanced countries are still not well coordinated to highlight the risk-factor or disease specificity [53]. The lack of coordination between evidence and action in the for example in USA can also be applied globally [25]. Many potential advocacy groups have their origins in specialist organizations of health professionals, and are not coordinated to generate a force as powerful promoters of broad prevention and control policies [16, 35]. This lack of advocacy for health promotion is not in line with the expanding commercial and consumer groups who have placed treatment at the centre of health policy debates and funding priorities [31].A powerful widely coordinated health alliances are necessary for main health professional organizations, consumer groups, corporate industries, and research institution to effectively manage the prevention of major risk factors for NCDs [14, 54].All efforts to promote research to address challenges in chronic non communicable diseases prevention, control are being promoted through research initiatives and stake holder funding opportunities. These challenges and the study research needs have been addressed in table 2 .

\begin{tabular}{|c|c|c|}
\hline & Major challenges & Study/Research needed to address goals \\
\hline $\begin{array}{l}\text { Goal A } \\
\text { Sensitization/ } \\
\text { Advocacy }\end{array}$ & $\begin{array}{l}\text { Increase the political priority of NCD } \\
\text { Encourage healthy lifestyle and consumers } \\
\text { choices through effective sensitization } \\
\text { advocacy and public engagement } \\
\text { sensitization } \\
\text { Assemble valid information for widespread } \\
\text { media coverage and sensitization of } \\
\text { economic, social and public health } \\
\text { programmes }\end{array}$ & $\begin{array}{l}\text { Engaging stakeholders in partnership for disease } \\
\text { prevention } \\
\text { How to create public forums to raise awareness of } \\
\text { issues relating to chronic NCDs } \\
\text { Promote research platform for health involving the } \\
\text { government some state sectors such as the health } \\
\text { eduction and environment, transportation } \\
\text { Research the causes for poor sensitization and } \\
\text { promoting awareness to chronic disease in the } \\
\text { community. }\end{array}$ \\
\hline $\begin{array}{l}\text { Goal B } \\
\text { Advancing } \\
\text { economic } \\
\text { legal and } \\
\text { environmental } \\
\text { policies }\end{array}$ & $\begin{array}{l}\text { The effect of poor health on economic output } \\
\text { and productivity } \\
\text { The effect State spending and taxation on } \\
\text { health } \\
\text { System to implement local, national and } \\
\text { international policies with trade regulation } \\
\text { policies on health related consumer } \\
\text { products. }\end{array}$ & $\begin{array}{l}\text { Quantify impact of chronic NCDs on local } \\
\text { economies } \\
\text { Program on the international implication of changes } \\
\text { in health related food consumption } \\
\text { Assess motivations associated with domestic } \\
\text { spending, and changing lifestyle choices } \\
\text { study the health effect of agriculture, climate change } \\
\text { and policy interventions } \\
\text { Research on health and economic effects of } \\
\text { developed community-based interventions }\end{array}$ \\
\hline
\end{tabular}


Setting up population metrics, health indicators program for policy and programme surveillance Research on the efficiency of food-labeling legislation and policies

\begin{tabular}{|c|c|c|}
\hline $\begin{array}{l}\text { Goal C } \\
\text { Programme } \\
\text { management of } \\
\text { possible } \\
\text { risk factors }\end{array}$ & $\begin{array}{l}\text { Knowledge of environmental and cultural } \\
\text { factors linked to social behavior changes } \\
\text { Enforcement of sustainable programmes to } \\
\text { minimize tobacco consumption } \\
\text { Promote healthy food intake in the } \\
\text { population } \\
\text { Develop sustainable physical activity } \\
\text { strategic programmes }\end{array}$ & $\begin{array}{l}\text { Study behavioral modifications to reduce risks } \\
\text { Study risk factors, and the factors associated or } \\
\text { affect risk in chronic NCDs. } \\
\text { Study new medical products for the prevention of } \\
\text { heart disease and diabetes } \\
\text { Study the socio-cultural, ethnic and genetic } \\
\text { diversity linked to risk factors that support } \\
\text { behavioral interventions } \\
\text { Assess personal risk linked to phenotypes, } \\
\text { genotypes and multiple risks factors } \\
\text { Evaluate genotype by environment interaction of } \\
\text { environment of genes in risk factors and the } \\
\text { outcomes } \\
\text { Research on new biomarkers and diagnostics for } \\
\text { risk and early disease diagnosis. }\end{array}$ \\
\hline $\begin{array}{l}\text { Goal D } \\
\text { Participation in }\end{array}$ & $\begin{array}{l}\text { Application of business models as main tool } \\
\text { to sensitize health and preventable disease } \\
\text { hDevelop business ethics and code of conduct } \\
\text { for the food ndustries } \\
\text { Enhance community resources such as } \\
\text { voluntary and NGOs }\end{array}$ & $\begin{array}{l}\text { Study marketing techniques and marketing data } \\
\text { resulting from commercial firms on behavioral } \\
\text { patterns. } \\
\text { Investigate the mechanisms for consumers and the } \\
\text { public have a positive influence on the food } \\
\text { industry } \\
\text { Research the impact of taste, packaging, labeling } \\
\text { and advertising on choice and health of consumers. } \\
\text { Create and evaluate community-based strategies to } \\
\text { promote healthy living } \\
\text { Source the method of effective public-private } \\
\text { partnerships to support health }\end{array}$ \\
\hline $\begin{array}{l}\text { Goal E } \\
\text { Identification the } \\
\text { health impacts on } \\
\text { poverty and } \\
\text { urbanization }\end{array}$ & $\begin{array}{l}\text { Study and address how poverty increases } \\
\text { risk factors } \\
\text { Study and address the links between } \\
\text { urbanization and chronic NCD }\end{array}$ & $\begin{array}{l}\text { Assess the relationship between poverty and the } \\
\text { risk associated to health } \\
\text { Examine the influence of poverty on the adoption of } \\
\text { high-risk behavior } \\
\text { Identify negative effects of economic growth on } \\
\text { health } \\
\text { Study the importance in town planning to promote } \\
\text { the environment on healthy living }\end{array}$ \\
\hline Goal F & $\begin{array}{l}\text { Strategies to mobilize resources in health } \\
\text { systems in function of the disease burden. }\end{array}$ & $\begin{array}{l}\text { Develop strategies that can incorporate a } \\
\text { sustainable health-system control/prevention of } \\
\text { non-communicable diseases }\end{array}$ \\
\hline
\end{tabular}




\begin{tabular}{|c|c|c|}
\hline & Major challenges & Study/Research needed to address goals \\
\hline $\begin{array}{l}\text { Reorientation of the } \\
\text { health system } \\
\text { platforms }\end{array}$ & $\begin{array}{l}\text { Direct capacity building of health } \\
\text { professional within prevention management, } \\
\text { Increase number and skills of professionals } \\
\text { in prevention and controlof chronic non- } \\
\text { communicable diseases } \\
\text { Built health systems that integrate screening } \\
\text { and prevention within health delivery } \\
\text { Increase access to medication to prevent } \\
\text { complications of chronic non-communicable } \\
\text { diseases }\end{array}$ & $\begin{array}{l}\text { Develop partnership work platforms to promote } \\
\text { best practices in delivering accessible, cheap health } \\
\text { care } \\
\text { Research on ways in supporting an organized } \\
\text { education on health promotion } \\
\text { Put in place roadmap for the promotion of health } \\
\text { training and development of courses targeted on } \\
\text { chronic non-communicable diseases } \\
\text { Provide local technical knowhow to enhance the } \\
\text { training of health personnel } \\
\text { Evaluate effective methods to promote optimal } \\
\text { resources distribution of health care in poor } \\
\text { communities } \\
\text { Promote and advocate the use of e-health records in } \\
\text { disease forecasting } \\
\text { Investigate effective means of developing practical } \\
\text { health surveillance tools. } \\
\text { Implementation of high throughput screening } \\
\text { mechanism that group the population according to } \\
\text { health disease predisposition risk factors. }\end{array}$ \\
\hline
\end{tabular}

Table 2. Global Challenges in chronic NCDs and advocacy tools for research needs [10, 53].

\subsection{Partnerships collaboration for addressing disease burden}

The challenges of non-communicable disease are so complex that there is a need for many stakeholders to collaborate in developing a control strategy. For improve the quality and regular access to quality healthy food, there is a need for a meaningful partnership collaboration between producers the consumer groups and the multinational food companies [13, 37]. The WHO has effectively developed a working to handle diet and physical activities with respect to the chronic diseases. This collaborative approach has seen the development of food regulatory guidelines, effective consultations process between WHO, the state, consumer groups, and many companies. Many food producing companies have reported the changes that is occurring in product labelling to reduce competition and promote marketing practices; if widely implemented, these changes could lead to significant benefits of globalization support to public health [40]. Other participatory partnership involving WHO involves working in close collaboration with the people and promote safe alcohol consumption.

\subsection{Building Capacity and resources platforms for non-communicable disease management}

Strengthening capacity for NCDs management is very important and must be promoted especially in low income economies where health information system management are not well developed. [20,26].Other constraints in building good resource platforms for NCDs is the 
slow institutional response to capacity strengthening, lack of vision and mission not align epidemiological survey activities. There is a need for creating an enabling environment for important financial commitment in different countries that may vary depending on the strategic planning programme put in place to build capacities that can plan and manage activities towards combating diseases and sustainable health of the population [9]. There are many initiatives at the national and international level to develop policies and working documents for NCDs management within the framework of public health sectorial health development portfolio, to what extend thses policies are effective can only be known when there is marked improvement or continuous increase in the management of patient health within a define country or jurisdiction.[15, 29].There has been a significant progress in building or promoting research partnership or collaboration by researchers at institutional, national and international level, a global advocacy for NCDs that has attracted some funding by potential donors in the health sector [53] There has been a significant progress made by international consortiums to support investment towards tobacco control research by building institutional research platforms in some developing countries and this is also being extended to other aspects of non-communicable diseases.

\section{Global norms and standards in the management of chronic non- communicable diseases}

In other to achieve success in NCDs management initiatives there must be respect for international standard norms and ethics regulating the health sector.

Each country needs to develop initiative to train health personnel's on international ethical code of conduct guiding or regulating clinical research for diseases affecting the population and the global trade regulatory issue of health related products [5, 53], The respect of ethical norms in the health sectorial research and development is still not a standard practice in the management of NCDs in developing countries.. Despite the creation of ethical committees and institutional review boards to regulate clinical research there are still problems that are linked to nutrition and lack of physical activity that are difficult to address.

Multi stakeholder and other state policies are initiatives geared towards the sensitization and advocacy to regulate the consumption and sales of food and alcohol especially for the younger population [11].

\subsection{Reorientation of health services towards management of non-communicable disease}

There has been significant increase in premature loss of lives as a result the lack of a sustainable management system for the control and prevention of NCDs. In some developed countries well developed and user-friendly intervention systems are available for CVD management and these are now successfully transferred to some privileged developing countries to support interventions in CVDs [30]. There has been a significant global initiative to develop an effective disease management system for cancer therapy. This system has contributed significant on the 
ease of diagnostics, the prevention and treatment and methods for procedures for palliative has also improved. [11, 21, 53]. Considering for example NCD like the of breast cancer and cervical cancer, that has also become a serious health concern in sub Saharan African countries, among women of child bearing age, there is no proper sensitization mechanism about the threat of this disease and the health implication for young child bearing women. In addition diagnostic tools and procedures are not well developed, and in most cases diagnostics are made only when severe cases are reported at the late stage of cancer at the hospitals, health districts or integrated health centres. In most countries of the central Africa sub regions the states has made a lot of effort to fight against cancer by creating health committee at the ministry of health, and a society for cancer research. Despite these initiative by the government the impact is not felt at the rural areas. Activities by some NGOs or other operational bodies is focused in the cities. There are many opportunities for coordinated non-communicable disease risk reduction, care, and long-term management.

\section{Conclusion}

The advancement of globalization of the major risks for non-communicable diseases is on a steady increase especially in resource countries plague with poverty, political and economic instability. On the other hand, the prospects for non-communicable chronic disease diagnosis, prevention and management and control is still generally at its infancy. We can attain a sustainable progress when the governments, stakeholders of international agencies, nongovernmental agencies, and civil society create an enabling environment and acknowledge the integration of non-communicable disease as a risk factor in the public health agenda. The challenges are enormous and the fight to promote healthy food consumption and maintenance of a healthy lifestyle towards reducing metabolic diseases or lifestyle diseases, like diabetes, hypertension, CVD will remain slow until the response or taskforce to NCD epidemics is well developed and structured to meet up with their disease burden. The advocacy and the importance of sensitization of the global community on the importance of non-communicable disease as a public health concern is no longer the responsibility of WHO but a global mobilization of nations, donors, stakeholder and greater promotion and encouragement of research funding opportunities. Advocacy for NCDs has gain so much priority of recent in the public health strategic disease prevention and control in most in Africa to the extent that in Cameroon and its Central African states there has been national and sub-regional consortium for the management of NCDs.

\section{Acknowledgements}

The authors would like to thank the European \& Developing Countries Clinical Trials Partnership (EDCTP) for the grant funding that enable us to realize part of this project. Furthermore we would also like to recognize the financial support of the Ministry of Higher Education (MINESUP) of Cameroon for the allocation of research subvention and moderni- 
zation financial support Research support of lecturers. Finally, we acknowledged the support of our data mining process system through the access to information sites and those who sent us research materials.

\section{Author details}

Estella Tembe-Fokunang ${ }^{1 *}$, Charles Fokunang ${ }^{1,2}$, Zacharia Sando $^{1}$, Barbara Atogho Tiedeu ${ }^{3}$, Frederick Kechia ${ }^{1}$, Valentine Ndikum ${ }^{1}$, Marceline Ngounoue Djuidje ${ }^{3}$, Jerome Ateudjieu ${ }^{1}$, Raymond Langsi ${ }^{2}$, John Fomnboh Dobgima ${ }^{2}$, Joseph Fokam ${ }^{1}$, Luc Gwum ${ }^{1}$, Obama Abena ${ }^{1}$, Tazoacha Asonganyii ${ }^{2}$, Jeanne Ngongang ${ }^{1}$, Vincent K. Titanji ${ }^{5}$ and Lazare Kaptue ${ }^{6,7}$

*Address all correspondence to: estellafokunang@yahoo.co.uk

1 Faculty of Medicine and Biomedical Sciences, University of Yaoundé, Cameroon

2 Faculty of Health Sciences, University of Bamenda, Cameroon

3 Faculty of Science, University of Yaoundé, Cameroon

Faculty of Science, University of Dschang, Cameroon

4 Faculty of Science, University of Buea, Cameroon

5 Universite des Montages, Cameroon

6 Cameroon National Ethics Committee for Research in Humans (CNERH), Cameroon

\section{References}

[1] Beaglehole R, Yach D,. Globalization and the prevention and control of non-communicable disease: the neglected chronic diseases of adults. The Lancet, 2003. 362 issue 9387:903-908.

[2] Wang W, Russell A, Yan Y; Global Health Epidemiology Reference Group (GHERG). Frailty, dependency and mortality predictors in a cohort of Cuban older adults. Frailty, 2003-2011. EPMA J. 2014 Feb 13;5(1):4.

[3] Zhou M, Liu Y, Wang L, Kuang X, Xu X, Kan H. Particulate air pollution and mortality in a cohort of Chinese men, Environ Pollut. 2014 Mar;186:1-6.

[4] Prescott SL, Pawankar R, Allen KJ, Campbell DE, Sinn JKh, Fiocchi A, Ebisawa M, Sampson HA, Beyer K, Lee BW.A global survey of changing patterns of food allergy burden in children. World Allergy Organ J. 2013 Dec 4;6(1):21. 
[5] Patel DN, Nossel C, Alexander E, Yach D. Innovative business approaches for incenting health promotion in sub-Saharan Africa: progress and persisting challenges Prog Cardiovasc Dis. 2013 Nov-Dec;56(3):356-62.

[6] Kengne AP, June-Rose McHiza Z, Amoah AG, Mbanya JC.Cardiovascular diseases and diabetes as economic and developmental challenges in Africa. Prog Cardiovasc Dis. 2013 Nov-Dec;56(3):302-13.

[7] Matheka DM, Nderitu J, Vedanthan R, Demaio AR, Murgor M, Kajana K, Loyal P, Alkizim FO, Kishore SP. Young professionals for health development: the Kenyan experience in combating non-communicable diseases. http://www.ncbi.nlm.nih.gov/ pubmed/24262308 Glob Health Action. 2013 Nov 20; 6:22461.

[8] Uchendu OJ, Forae GD. Disese mortality patterns in elderly patients: A Nigerian teaching hospital experience in Irrua, Nigeria. Niger Med J. 2013 Jul; 54(4):250-3.

[9] Okpechi IG, Chukwuonye II, Tiffin N, Madukwe OO, Onyeonoro UU, Umeizudike TI, Ogah OS. Blood pressure gradients and cardiovascular risk factors in urban and rural populations in Abia State South Eastern Nigeria, using the WHO Stepwise approach.PLoS One. 2013 Sep 5;8(9):

[10] Kankeu HT, Saksena P, Xu K, Evans DB. The financial burden from non communicable diseases in low-middle-income countries: a literature review. Health Res Policy Syst. 2013 Aug 16; 11:31.

[11] Turk T, Latu N, Cocker-Palu E, Liavaa V, Vivili P, Gloede S, Simons A. Using rapid assessment and response to operationalise physical activity strategic health communication campaigns in Tonga. Health Promot J Austr. 2013 Apr; 24(1):13-9..

[12] Roberts B, Patel P, Dahab M, McKee M. The Arab Spring: confronting the challenge of non-communicable disease. J Public Health Policy. 2013; 34(2):345-52..

[13] Angkurawaranon C, Wattanatchariya N, Doyle P, Nitsch D. Urbanization and noncommunicable disease mortality in Thailand: an ecological correlation study. http:// www.ncbi.nlm.nih.gov/pubmed/23279597 Trop Med Int Health. 2013; 18(2):130-40.

[14] Robinson HM, Hort K.Non communicable diseases and health systems reform in low and middle income countries. Pac Health Dialog. 2012 18(1):179-90.

[15] Silva-Matos C, Beran D.Non-communicable diseases in Mozambique: risk factors, burden, response and outcomes to date. Global Health. 2012 21; 8:37.

[16] Remais JV, Zeng G, Li G, Tian L, Engelgau MM. Conversion of noncommunicable and infectious diseases in low and middle-income countries. Int J Epidemiol. 2013 42(1):221-7.

[17] Joshi A, Mohan K, Grin G, Perin DM. Burden of healthcare utilization and out of pocket costs among individuals with NCDs in an Indian setting. J Community Health. 2013 Apr; 38(2):320-7. 
[18] Crowther NJ, Early determinants of chronic disease in developing countries. Best Pract Res Clin Endocrinol Metab. 2012 Oct; 26(5):655-65.

[19] Jones AC, Geneau R. Assessing research activity on priority interventions for noncommunicable disease prevention in low and middle income countries.Glob Health Action. 2012 23; 5:1-13.

[20] Michaelsen KF, Larnkjær A, Mølgaard C.Amount and quality of dietary proteins during the first two years of life in relation to NCD risk in adulthood. Nutr Metab Cardiovasc Dis. 2012; 22(10):781-6.

[21] Lopez, A. D., Mathers, C. D., Ezzati, M., Jamison, D. T. \& Murray, C. J. L. (eds) Global Burden of Disease and Risk Factors (Oxford Univ. Press and World Bank, Washington DC, 2006).

[22] World Health Organization Preventing Chronic Diseases: A Vital Investment (WHO, Geneva, 2005).

[23] Adeyi, O., Smith, O. \& Robles, S. Public Policy and the Challenge of Chronic Noncommunicable Diseases (World Bank, Washington DC, 2007).

[24] Suhrcke, M., Nugent, R. A., Stuckler, D., \& Rocco, L. Chronic Disease: An Economic Perspective (Oxford Health Alliance, London, 2006).

[25] Zwi AB, Yach D. International health in the 21st century: trends and challenges. Soc Sci Med 2002; 54: 1615-1620.

[26] WHO. The world health report 2012. Geneva: World Health Organization, 2012.

[27] Stamler J, Stamler R, Neaton JD, et al. Low risk-factor profile and long-term cardiovascular and non-cardiovascular mortality and life expectancy. Findings for 5 large cohorts of young adult and middle-aged men and women. JAMA 1999; 282: 2012-2018.

[28] Magnus P, Beaglehole R. The real contribution of the major risk factors to the coronary epidemics: time to end the 'only 50\%' claim. Ann Int Med 2001; 161: 2657-2660.

[29] United Nations. Conference on trade and development. Least developed countries report 2002: escaping the poverty trap. Geneva: United Nations, 2002.

[30] Bettcher DW, Yach D, Guindon GE. Global trade and health: key linkages and future challenges. Bull World Health Organ 2000; 78: 521-534.

[31] Ong EK, Glantz SA. Constructing "sound science" and good epidemiology": tobacco lawyers and public relations firms. Am J Public Health 2001; 91: 1749-1757?

[32] Yach D, Bialous SA. Junking science to promote tobacco. Am J Public Health 2001; 91: $1745-1748$ ? 
[33] Popkin BM. The Bellagio Conference on the Nutrition Transition and its Implications for Health in the Developing World. Bellagio, Italy, Aug 20-24, 2001. Public Health Nutr 2002; 5: 93-280.

[34] Popkin BM. An overview on the nutrition transition and its health implications: the Bellagio meeting. Public Health Nutr 2002; 5: 93-103.

[35] Ebbeling CD, Pawlak DB, Ludwig DS. Childhood obesity: public-health crisis, common sense cure. Lancet 2002; 360: 473-482.

[36] Beaglehole R, Dobson A. The contributions to change: risk factors and the potential for prevention. In: Marmot M, Elliott P, eds. Coronary heart disease epidemiology. Oxford: Oxford University Press, 2003.

[37] Beaglehole R. Global cardiovascular disease prevention: time to get serious. Lancet 2001; 358: 661-663.

[38] Kahn EB, Ramsey L, Brownson RC, The effectiveness of interventions to increase physical activity: a systematic review. Am J Prev Med 2002; 22: 73-107,

[39] McGinnis JM. Does proof matter? Why strong evidence sometimes yields weak action. Am J Health Promot 2001; 15: 391-396.

[40] Yusuf S. Two decades of progress in preventing vascular disease. Lancet 2002; 360: 2-3.

[41] Ala Din Alwan Gauden Galea David Stuckler. Development at risk: addressing noncommunicable diseases at the United Nations high-level meeting.Bulletin of the World Health Organization 2011; 89:546-546A. doi: 10.2471/BLT.11.091074.

[42] Shoaee S, Ghasemian A, Najafi B, Kasaeian A, Farzadfar F, Hessari H. National and subnational burden of oral diseases in Iran. 1990-2013 study protocol. Arch Iran Med. 2014 Mar; 17(3):159-68.

[43] Ghasemian A, Ataie-Jafari A, Khatibzadeh S, Mirarefin M, Jafari L, Nejatinamini S, Parsaeian M, Peykari N, Jamshidi HR, Ebrahimi M, Etemad K, Moradi-Lakeh M, Farzadfar F.National Arch Iran Med. 2014 ;17(3):146-58.

[44] de Morais C, Oliveira B, Afonso C, Lumbers M, Raats M, de Almeida MD.Nutritional risk of European elderly.Eur J Clin Nutr. 2013 Nov; 67(11):1215-9.

[45] James J, Soyibo AK, Hurlock L, Gordon-Strachan G, Barton EN.The cardiovascular risk factors in an Eastern island prevalence of the non communicable chronic diseases and associated lifestyle risk factors for cardiovascular morbidity and mortality in the British Virgin Islands. West Indian Med J. 2012 Jul; 61(4):429-36.

[46] Mortality and burden of disease estimates for WHO Member States in 2004. Geneva: World Health Organization; 2009. 
[47] Narayan KM, Ali MK, Koplan JP. Global non-communicable diseases - where worlds meet. N Engl J Med 2010; 363: 1196-8

[48] Jha P, Jacob B, Gajalakshmi V, Gupta PC, Dhingra N, Kumar R, et al., et al. A nationally representative case-control study of smoking and death in India. N Engl J Med 2008; 358: 1137-1147.

[49] Mahal A, Karan A, Engelgau M. The economic implications of non-communicable disease for India. Washington: The World Bank; 2010.

[50] Adeyi O, Smith O, Robles S. Public policy and the challenge of chronic non-communicable diseases. Washington: The World Bank; 2007.

[51] Jamison D, Breman JG, Measham AR, Alleyne G, Claeson M, Evans DB, et al. Disease control priorities in developing countries. Washington: The World Bank; 2006.

[52] Daar AS, Singer PA, Persad DL, Pramming SK, Matthews DR, Beaglehole R, et al., et al. Grand challenges in chronic non-communicable diseases. Nature 2007; 450: 494-6

[53] Global status report on noncommunicable diseases 2010. Geneva: World Health Organization; 2011.

[54] Stuckler D. Population causes and consequences of leading chronic diseases: a comparative analysis of prevailing explanations. Milbank Q 2008; 86: 273-326

[55] Nugent R, Feigl A. Scarce donor funding for non-communicable diseases: will it contribute to a health crisis? Washington: Center for Global Development; 2010.

[56] Alleyne G, Stuckler D, Alwan A. The hope and the promise of the UN Resolution on non-communicable diseases. Global Health 2010; 6: 15 - 
